\title{
Tartrazine induced changes in physiological and biochemical parameters in Swiss albino mice, Mus musculus
}

Sayema Arefin, Mohammad Salim Hossain, Shamme Akter Neshe, Md. Mamun Or Rashid, Mohammad Tohidul Amin, Md. Saddam Hussain

\begin{abstract}
Now-a-days synthetic food dyes are being used most commonly as food colorant in confectionaries, drugs and cosmetics. Present study was designed to evaluate the toxic effect of tartrazine, a widely used azo dye, on Swiss Albino mice. Experimental animals were treated with tested dye at a dose level $200 \mathrm{mg} / \mathrm{kg} \& 400 \mathrm{mg} / \mathrm{kg}$ body weight along with normal diet. Various physiological and biochemical parameters were assessed to study the toxic effect of tartrazine. Our study revealed a highly noticeable decrease in the body weight gain
\end{abstract}

of mice at $400 \mathrm{mg} / \mathrm{kg}$ dose compared with the control group. A significant variation in the average weight of the major organs (heart, kidney and liver) was also observed. The average weights of the heart and kidney were increased whereas the average weight of liver was decreased significantly. Serum triglyceride, creatinine and bilirubin levels were significantly increased, in contrast cholesterol level was decreased in the groups of mice treated with tartrazine.

Keywords: Azo-Dye, tartrazine, Swiss Albino Mice, Physiological changes, Serum biochemistry.
Sayema Arefin, Mohammad Salim Hossain, Shamme Akter Neshe, Md. Mamun Or Rashid, Mohammad Tohidul Amin, Md. Saddam Hussain Department of Pharmacy, Noakhali Science and Technology University, Noakhali-3814, Bangladesh

Corresponding Author:

Mohammad Salim Hossain

pharmasalim@yahoo.com
Submitted / Gönderilme: 30.12.2016

Accepted / Kabul: $\quad 06.02 .2017$

Revised / Düzeltme: 03.02.2017

\section{INTRODUCTION}

Color has become an essential part of food processing, as it can influence the perceived flavor of foods by the consumers. In order to make food more appealing and attractive, the practice of addition of color to foods has been being continued for centuries. Today consumers rely on the technological, aesthetic and convenient benefits provided by the color additives. Although these additives may come from both natural and synthetic origin, however $95 \%$ of those used now-a-days are synthetic because they are produced easily, cheaper and provide better coloration (1). Among the different dyes, Tartrazine, also known as FD\&C yellow 5, is frequently used in foods, drugs, and cosmetics (2).

The use of artificial dye in wide ranges of food is being suspected to be toxic or harmful. Tartrazine has been reported to produce allergic reactions in atopic eczema and sensitive individuals (3-5). Moreover tartrazine has toxic potential for human lymphocyte (6), learning and memory functions (7) and behavior in children (8). But in case of carcinogenic effect, the role of tartrazine is ambiguous as different studies reported differently $(9,10)$. Different food dye like chocolate brown has been reported to alter the serum biochemistry (11). Although several toxic effects of 
Tartrazine has been reported but alteration of biochemical and physiological functions with Tartrazine is not well understood. This current study was aimed to find out the physiological and biochemical changes in Swiss albino mice in relatively higher dose of tartrazine as a safety concern. The outcome of this study will help us to make decision in using of tartrazine as food dye.

\section{MATERIALS AND METHODS}

\subsection{Materials}

Tartrazine (C.I. 19140, CAS No 1934-21-0, Mw 534.37, synonyms: E 102, Food yellow 4, FD\&C yellow No.5) was obtained from local market.

\subsection{Animal's model and housing}

Swiss Albino mice are widely used in toxicology research because they respond favorably. Healthy Swiss albino mice (25-30g) were collected from Department of Pharmacy, Jahangirnagar University, Savar, Dhaka, Bangladesh and were kept in polypropylene plastic cages having dimensions of $30 \times 20 \times 13 \mathrm{~cm}$ and soft wood shavings were employed as bedding in the cages. Feeding of animal was done along with standard laboratory pellet diet and water at libitum, exposing them to alternate cycle of $12 \mathrm{hr}$ dark and light, at temperature $25 \pm 20^{\circ} \mathrm{C}$ and relative humidity $55 \pm 10 \%$. All the mice were allowed to acclimatize for 7 days to the laboratory conditions before conducting the experiment.

\subsection{Study protocol}

Fifteen experimental healthy animals were randomly selected and divided into three groups with 5 animals in each group.

Group-1: Control group

Group-2: Mice treated with dye at $200 \mathrm{mg} / \mathrm{kg}$ body weight (b.w.) dose

Group-3: Mice treated with dye at $400 \mathrm{mg} / \mathrm{kg}$ b.w. dose

Tartrazine dye was administered orally, using an intra-gastric feeding syringe for an experimental period of 25 days. A daily record of body weight was maintained. At the end of the study, the animals were weighed and sacrificed by cervical dislocation. The body organs and the blood samples were collected to analyze the toxic effect caused by the tartrazine. This study protocol was approved from the institutional committee.

\subsection{Monitoring of body weight}

To observe the effect of chronic administration of the tartrazine on growth rates of the experimental animals, body weight of all of the experimental mice including the controlled group, were carefully monitored throughout the 25 days period of dye administration.

This following equation described previously $(11,18)$ was used to calculate the percentage of body weight gain.

Mean final weight - Mean initial weight

$\%$ Body weight gain X 100

Mean initial body weight

\subsection{Biochemical analysis of blood}

To collect the intended serum and to remove red blood cells, the collected samples of blood were centrifuged at $1000 \mathrm{~g}$ for 10 min using bench top centrifuge (MSE Minor, England). After separation, serum was collected carefully and stored in the refrigerator at $-20^{\circ} \mathrm{C}$ for analysis. The analysis of all the biochemical parameter was accomplished within $24 \mathrm{~h}$ of sample collection. All of the analyzes were conducted with respective analysis kit e.g Triglyceride kit (CAT\# CS 611, Crescent Diagnostics, Soudia Arabia), Cholesterol kit (CAT\# CH 200, Randox Laboratories, UK), Creatinine kit (CAT \# CR510, Randox Laboratories, UK), Bilirubin kit (CAT\# CS 601/602, Crescent Diagnostics, Soudia Arabia) according to the manufacturer's instructions. The absorbance was measured using a spectrophotometer JA.S.CO V-530 (UV/ vis), Japan.

\subsection{Pathological examination}

After sacrificing the experimental animals, specific organs of interest were then separated and preserved in normal saline for 24 hours. After collecting the organs and drying, the weight of each organ of each mice was measured separately and the average weights were compared for statistical evaluation.

\subsection{Statistical analysis}

All the results obtained by in-vitro and in-vivo experiment are presented in the tables or figures as the mean \pm SEM. The statistical significance of the differences between control and experimental groups was evaluated by paired $t$-test (using SPSS software, version-20), where $\mathrm{p}<0.05$ was considered as statistically significant. 


\section{RESULTS}

\subsection{Clinical observation, Food intake, Body weight and} Growth

Treatment with tartrazine did not affect mortality, clinical signs, food intake when compared to the control group.

As a function of growth, body weight of experimental animal was monitored. Our data showed a noticeable retardation in the body weight gain in mice treated with relatively large dose $(400 \mathrm{mg} / \mathrm{kg}$ b.w.) of tartrazine but at $200 \mathrm{mg} / \mathrm{kg}$ b.w. did not affect the body weight gain significantly. Results are presented in Table 1.

\subsection{Organ weight}

With regard to the organ weight, average weight of heart of the mice has been increased significantly in tartrazine treated groups $(\mathrm{p}=<0.05)$. Statistically insignificant increase in the average weight of kidney was also reported in the tartrazine treated groups of animal but a significant decrease in the average weight of liver was noticed in case of tartrazine administration to mice. All the data has been presented in Table 2 .

Table 1. Changes in the body weight gain of the mice during the 25 day period of study.

\begin{tabular}{|c|c|c|c|}
\hline \multirow[t]{2}{*}{ Treatment } & \multicolumn{2}{|c|}{$\begin{array}{l}\text { Body Weight (g) } \\
(\text { Mean } \pm \text { S.E.M.) }\end{array}$} & \multirow[t]{2}{*}{$\begin{array}{c}\% \text { of Body } \\
\text { Weight gain }\end{array}$} \\
\hline & Initial & Final & \\
\hline $\begin{array}{l}\text { Group-1 } \\
\text { (Control) }\end{array}$ & $26.97 \pm 0.53$ & $33.54 \pm 0.84$ & 6.57 \\
\hline $\begin{array}{l}\text { Group-2 } \\
(200 \mathrm{mg} / \mathrm{kg} \text { b.w })\end{array}$ & $27.39 \pm 0.44$ & $35.01 \pm 0.86$ & 7.62 \\
\hline $\begin{array}{l}\text { Group- } 3 \\
(400 \mathrm{mg} / \mathrm{kg} \text { b.w })\end{array}$ & $27.68 \pm 0.24$ & $32.05 \pm 0.77^{*}$ & $4.40^{*}$ \\
\hline
\end{tabular}

Values are represented as mean $\pm \operatorname{SEM}(n=5) ;{ }^{*} \mathrm{p}<0.05$ versus control

Table 2. Effect of tartrazine on the average weight of heart, kidney and, liver of mice

\begin{tabular}{lccc}
\hline Treatment & Heart $(\mathbf{g m})$ & Kidney $(\mathbf{g m})$ & Liver $(\mathbf{g m})$ \\
\hline $\begin{array}{l}\text { Group-1 } \\
\text { Control })\end{array}$ & $0.184 \pm 0.003$ & $0.314 \pm 0.036$ & $1.931 \pm 0.021$ \\
Group-2 & $0.275 \pm 0.011^{*}$ & $0.397 \pm 0.011$ & $1.75 \pm 0.03^{*}$ \\
$(200 \mathrm{mg} / \mathrm{kg} \mathrm{b.w)}$ & & & $1.76 \pm 0.029^{*}$ \\
Group- 3 & $0.212 \pm 0.015^{*}$ & $0.42 \pm 0.029$ & \\
$(400 \mathrm{mg} / \mathrm{kg}$ b.w $)$ & & & \\
\hline
\end{tabular}

Values are represented as mean $\pm \operatorname{SEM}(\mathrm{n}=5) ;{ }^{\star} \mathrm{p}<0.05$ versus control

Table 3. Effect of tartrazine on Cholesterol, Triglyceride, Bilirubin, Creatinine

\begin{tabular}{lcccc}
\hline Treatment & Cholesterol (mg/dl) & $\begin{array}{c}\text { Triglyceride } \\
(\mathbf{m g} / \mathbf{d l})\end{array}$ & $\begin{array}{c}\text { Bilirubin } \\
(\mathbf{m g} / \mathbf{d l})\end{array}$ & Creatinine (mg/dl) \\
\hline Group-1 (Control) & $161.539 \pm 2.29$ & $232.22 \pm 6.75$ & $6.601 \pm 0.28$ & $0.79 \pm 0.18$ \\
Group-2 & $156.154 \pm 5.26$ & $207.41 \pm 9.79$ & $8.27 \pm 0.23^{* *}$ & $1.48 \pm 0.21$ \\
$(200 \mathrm{mg} / \mathrm{kg}$ b.w $)$ & $151.923 \pm 4.81$ & & & $1.78 \pm 0.25^{* *}$ \\
Group-3 & & $288.97 \pm 12.76^{*}$ & $8.36 \pm 0.23^{* *}$ & \\
$(400 \mathrm{mg} / \mathrm{kg}$ b.w $)$ & & & & \\
\hline
\end{tabular}

Note: values are represented as mean $\pm \operatorname{SEM}(n=5) ;{ }^{*} \mathrm{p}<0.05,{ }^{* *} \mathrm{p}<0.01$ versus control 


\subsection{Biochemical examination}

Data presented in Table 3, showed the different biochemical parameter tested in this experiment. We found a statistically insignificant decrease in the cholesterol level in mice treated with tartrazine regardless of dose than that the control group. Whereas, the concentration of triglyceride was increased in mice treated with tartrazine. Dose at $400 \mathrm{mg} / \mathrm{kg}$ b.w showed statistically significant $(\mathrm{p}<0.05)$ increase in triglyceride level but at lower dose $200 \mathrm{mg} / \mathrm{kg}$ b.w this changes was insignificant.

Tartrazine was able to increase the serum bilirubin significantly $(\mathrm{p}<0.01)$ in a dose dependent manner. Again serum creatinine level was also increased $(\mathrm{p}<0.01)$ in both tartrazine treated group.

\section{DISCUSSION}

Toxic effects of tartrazine were evaluated in this experiment with a chronic administration of dye. The acceptable daily intake of tartrazine for human is $0-7.5 \mathrm{mg} / \mathrm{kg}$-b.w (12). Poul et al (13) studied that tartrazine up to $1000 \mathrm{mg} / \mathrm{kg}$-b.w twice at 24 hours interval did not produce any genotoxic activity in mice. Whereas, Amin et al (21) reported the alteration of renal, and hepatic functions by tartrazine at $500 \mathrm{mg} / \mathrm{kg}$-b.w dose repeated for 30 days in rats. Considering these findings and to assess the toxicity arising from chronic dose of tartrazine, a dose level of $200 \mathrm{mg} / \mathrm{kg}$-b.w and $400 \mathrm{mg} / \mathrm{kg}$-b.w with repeated administration up to 25 days, was evaluated in this study. During the whole period of treatment no death, no abnormal clinical signs of experimental mice were observed.

Monitoring of body weight is considered as proper growth of animal or human. Some researchers considered the loss of body weight is a reliable sensitive indicator for toxicity study $(14,15)$. In our study, a noticeable retardation in the body weight gain was found in mice treated with $400 \mathrm{mg} / \mathrm{kg}$ b.w than that of control group. This observation was in similarity with the other works done where a significant decrease in body weight was found in the mice treated with tartrazine (16). Thus the result indicates the potentiality of tartrazine to alter the growth as a function of toxicity. Along with the role in growth, we studied the effect of tartrazine on different organ weight. Tatrazine was capable to increase the weight of vital organs i.e heart and kidney of mice effectively but average liver weight was decreased. It was reported that oral ingestion of synthetic dyes such Fast Green $(12.5 \mathrm{mg} / \mathrm{kg} /$ day $)$ and Sunset Yellow ( $5 \mathrm{mg} / \mathrm{kg} /$ day) for 30 days in mice increased the liver and kidney weight $(17,18)$. While Maekawa et al. (10) indicated that subchronic tartrazine ingestion in rats decreased the absolute and relative liver in 2\% dose group. As the change of the absolute and relative organs weight is a sign of toxicity thus it is obvious that our experimental dye must have considerable toxicity on respective organ of the test animals.

Mehedi et al. (18) reported the intestinal lymphocyte infiltration, glomerular changes and edema in kidney after the administration of tartrazine, these pathophysiological changes may be attributed to our finding of elevated kidney weight. Furthermore, to investigate the function of kidney, we assessed the serum creatinine level and we found an elevated serum creatinine concentration in mice treated with tartrazine as predicted. Elevated serum creatinine is considered as renal dysfunction (19). Thus our result revealed that tartrazine has the potentiality to develop renal dysfunction.

In case of hepatoactivity, we found decreased liver weight and elevated serum total bilirubin in mice treated with tartazine. Both the doses applied here, were capable of doing the same function in dose dependent manner. Thus interpreting our study result, it can be said that tartrazine dye might cause in obstruction in liver function that increased the serum bilirubin level in the mice. This data is similar to our previous data the data where we observed a significant elevation in serum bilirubin level with other azo dyes like chocolate brown (11). Serum bilirubin concentration may be elevated due to acute hepatocellur injury, cholestatic injury or biliary obstruction. Moreover, the increased concentration of bilirubin may also be attributed to the hemolytic destruction of $\mathrm{RBC}$ as bilirubin is a waste product, that is primarily produced by the normal breakdown of heme, a substance found mainly in the protein hemoglobin in red blood cells (RBCs) (20).

To assess the effect of tartrazine on lipid profile, we examined the serum concentration of triglyceride and cholesterol. Our data showed that, tartrazine, regardless of dose, was capable to decrease cholesterol level insignificantly but in contrast, hypertriglyceridemia was observed in test animal when compared to the control group. The ability to elevate the triglyceride level was dose dependent manner. At higher dose, the effect was statistically significant. Our result agreed with the result of Amin et al. who observed a reduction in serum cholesterol level and an increase in triglyceride level in male rats treated with different azo dye (21). Although, other researchers showed the elevated level of triglyceride and cholesterol as an effect of azo dyes $(15,19)$. This dissimilarity in results may be due to the differences of doses applied in 
different studies. Moreover, elevation of serum triglyceride has been documented due to the deficit production of hepatic lipase in human $(22,23)$. Thus it might happen that damaged hepatocytes were unable to produce sufficient hepatic lipase to reduce the triglyceride in tartrazine treated test animal.

The wide use of tartrazine in foods, drinks, sweets, and cosmetics is a concern as a possibility of randomly exposure to this dye. Consumptions of tartrazine more than acceptable daily intake by children has been reported in different developing country like India (24), because the children are very fond of colored food. Chronic administration of tartrazine is associated with different toxic effect. Thus, exposure of excessive clororants like tartrazine in children may pose a health risk.

Swiss albino farelerde-Mus musculus, tartrazin'in neden olduğu fizyolojik ve biyokimyasal parametrelerindeki değişiklikler

öz

Günümüzde sentetik gıda boyaları, şekerlemelerde, ilaçlarda ve kozmetiklerde renklendirici olarak sıklıkla kullanılmaktadır. Çalışmamızda, geniş kullanım alanı olan bir azo boyar maddetartrazin'in Swiss albino farelerdeki toksik etkilerinin tespit edilmesi hedeflendi. Normal diyetle beslenen laboratuvar hayvanlarına tartrazin $200 \mathrm{mg} / \mathrm{kg}$ ve $400 \mathrm{mg} / \mathrm{kg}$ dozlarda uygulandı. Tartrazin'in toksik etkisini incelemek için çeşitli fizyolojik ve biyokimyasal parametreler değerlendirildi.

\section{CONCLUSION}

In conclusion, administration of azo dye tartrazine to mice causes many problems in the physiological and biochemical parameters particularly at higher dose. So ingestion of tartrazine containing food might not be free from harmful effects in the long run. Therefore awareness among people should be created about the hazardous effect of tartrazine consumption.

\section{Conflict of interest}

None
Çalışmamızda tartrazin’in $400 \mathrm{mg} / \mathrm{kg}$ dozunda uygulandığı grupta yer alan farelerde kontrol grubuna kiyasla vücut ağırlığ artı̧ında belirgin bir düşüş olduğu tespit edildi.

Kalp, böbrek ve karaciğer gibi hayatî organların ortalama ağırlı̆ı̆nda önemli farklılıklar gözlendi. Kalbin ve böbreklerin ortalama ağırlıkları artarken, karaciğerin ortalama ağırlı̆̆ı önemli derecede azaldığı tespit edildi. Tartrazin'in uygulandığı grupta yer alan farelerde serum trigliserid, kreatinin ve bilirubin düzeyleri anlamlı olarak artarken kolesterol düzeyinin azaldığı tespit edildi.

Keywords: Azo boyaları, Tartrazin, Swiss Albino fare, Fizyolojik değişiklikler, Serum biyokimyası

\section{References}

1. Saxena B, Sharma S. Serological changes induced by blend of sunset yellow, Metanil yellow and tartrazine in swiss albino rat, Rattus norvegicus. Toxicol Int 2014;21:65-8.

2. Himri I, Bellahcen S, Souna F, Belmekki F, Aziz M, Bnouham M, Zoheir J, Berkia Z, Mekhfi H, Saalaoui E. A 90-day oral toxicity study of Tartrazine, a synthetic food dye, in Wistar rats. Int J Pharm Pharm Sci 2011;3: 159-69.

3. Devlin J, David TJ. Tartrazine in atopic eczema. Arch Dis Child 1992; 67: 709-11.

4. Inomata N, Osuna H, Fujita H, Ogawa T, Ikezawa Z. Multiple chemical sensitivities following intolerance to azo dye in sweets in a 5-year-old girl. Allergol Int 2006;55:203-5.

5. Hannuksela M, Haahtela T. Food additive hypersensitivitynear myth. Duodecim 2009; 125:527-32.

6. Mpountoukas P, Pantazaki A, Kostareli E, Christodoulou P, Kareli D, Poliliou S. Cytogenetic evaluation and DNA interaction studies of the food colorants Amaranth, Erythrosine and Tartrazine. Food Chem Toxicol 2010;48: 2934-44.

7. Gao Y, Li C, Shen J, Yin H, An X, Jin H. Effect of food azo dye tartrazine on learning and memory functions in mice and rats, and the possible mechanisms involved. J Food Sci 2011;76:T125-9.

8. Rowe KS, Rowe KJ. Synthetic food coloring and behavior: A dose response effect in a double-blind, placebo-controlled, repeated measures study. J Pediat 1994;125:691-8.

9. Borzelleca, JF, Hallagan JB. Chronic toxicity/carcinogenicity studies of FD \& C yellow $n^{\circ} 5$ (Tartrazine) in rats. Food Chem Toxicol 1988;26: 179-87.

10. Maekawa A, Matsuoka C, Onodera H, Tanigawa H, Furuta K, Kanno J, Jang JJ, Hayashi Y, Ogiu T. Lack of Carcinogenecity of Tartrazine (FD \& C YELLOW No 5) in the F344 Rat. Food Chem Toxicol 1987;25:891-6.

11. Neshe SA, Arefin S, Hussain MS., Das A, Karmakar P, Hossain MS. Safety evaluation of chocolate brown dye in Swiss albino mice. J Nutr Disorders Ther 2016; 6:195.

12. Joint FAO/WHO Expert Committee on Food Additives: Specifications for the identity and purity of food additives and their toxicological evaluation: Food colors and some antimicrobials and antioxidants (JECFA) 1965. 
13. Poul M, Jarry G, Elhkim MO, Poul JM. Lack of genotoxic effect of food dyes amaranth, sunset yellow and tartrazine and their metabolites in the gut micronucleus assay in mice. Food Chem Toxicol 2009;47:443-8.

14. Aboel-Zahab H, El-Khyat Z, Sidhom G, Awadallah R, Abdelal W, Mahdy K. Physiological effects of some food coloring additives on rats. Boll Chim Farm 1997;136:615-27.

15. Helal GE, Zaahkouk AM, Mekkaway AH. Effect of some food colorants (Synthetic and Natural Products) of young Albino rats. Egyptian J Hosp Med 2000;1:103-13.

16. Sharma G, Gautam D, Goyal RP. Tartrazine induced haematological and serological changes in female Swiss albino mice, Mus musculus. Pharmacologyonline 2009;3: 774-8.

17. Osman MA, Afifi A, Hussein RM, Kamilia B, Abdel Aziz I, Salah SH. Long-Term biochemical and genotoxicity studies of four synthetic food and drug colorants in mice. Bull Faculty Pharm (Cairo Univ.) 1995;1:13-21.

18. Mehedi N, Mokrane N, Alami O, Tabet SA, Zaoui C, Kheroua O, Saidi D. A thirteen week ad libitum administration toxicity study of tartrazine in Swiss mice. Afr J Biotechnol 2013;12: 4519-29.
19. Timbrell JA. Principles of biochemical toxicology, 4th edition. Informa Healthcare, New York. 2009.

20. Al-Shinnawy MS, Elkattan NA. Assessment of the changes in some diagnostic parameters in male albino rats fed on an azo yye. Int J Environ Sci Eng 2013; 4:85-90.

21. Amin KA, Abdel Hameid H, AbdElsttar AH. Effect of food azo dyes tartrazine and Carmoisine on biochemical parameters related to renal, hepatic function and oxidative stress biomarkers in young male rats. Food Chem Toxicol 2010;48:2994-9.

22. Breckenridge WC, Little JA, Alaupovic P, Wang CS, Kuksis A, Kakis G, Lindgren F, Gardiner G. Lipoprotein abnormalties associated with a familial deficiency of hepatic lipase. Atherosclerosis 1982; 45:161-79.

23. Connely PW, Maruire GF, Lee M, Little JA. Plasma lipoproteins in familial hepatic lipase deficiency. Arteriosclerosis 1990;10:40-8.

24. Dixit S, Purshottam SK, Khanna SK, Das M. Usage pattern and exposure assessment of food colours in different age groups of consumers in the state of Uttar Pradesh, India. Food Addit Contam Part A Chem Anal Control Expo Risk Assess 2010;27:181-9. 